Supporting Information for

\title{
Achieving low-voltage, high-mobility IGZO transistor through ALD-derived bi-layer channel and hafnia-based gate dielectric stack
}

Min Hoe Cho ${ }^{1}$, Cheol Hee Choi ${ }^{1}$, Hyeon Joo Seul ${ }^{1}$, Hyun Cheol Cho ${ }^{1}$, and Jae Kyeong Jeong*,1

${ }^{1}$ Department of Electronic Engineering, Hanyang University, Seoul 04763, South Korea AUTHOR EMAIL ADDRESS: J. K. Jeong (jkjeong1@ hanyang.ac.kr). 

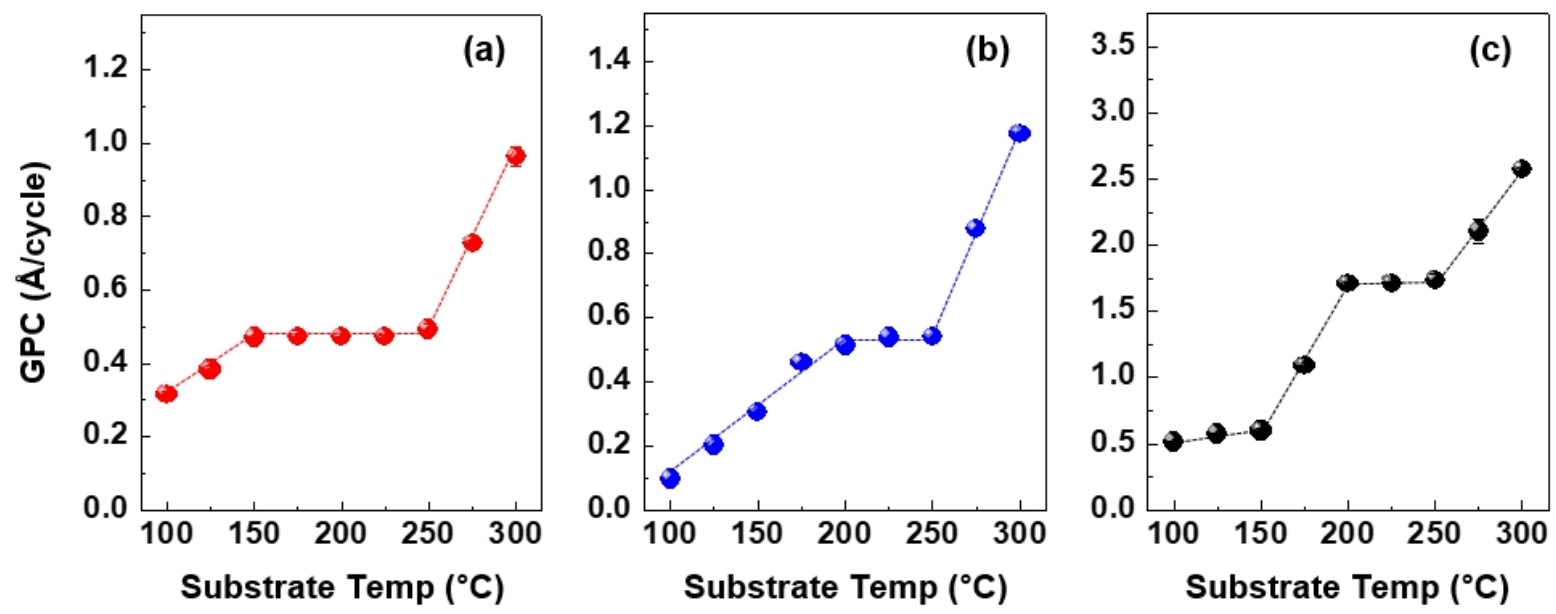

Figure S1. The growh rate per cycle (GPC) of (a) $\mathrm{In}_{2} \mathrm{O}_{3}$, (b) $\mathrm{Ga}_{2} \mathrm{O}_{3}$, and (c) $\mathrm{ZnO}$ as a function of substrate temperature. 


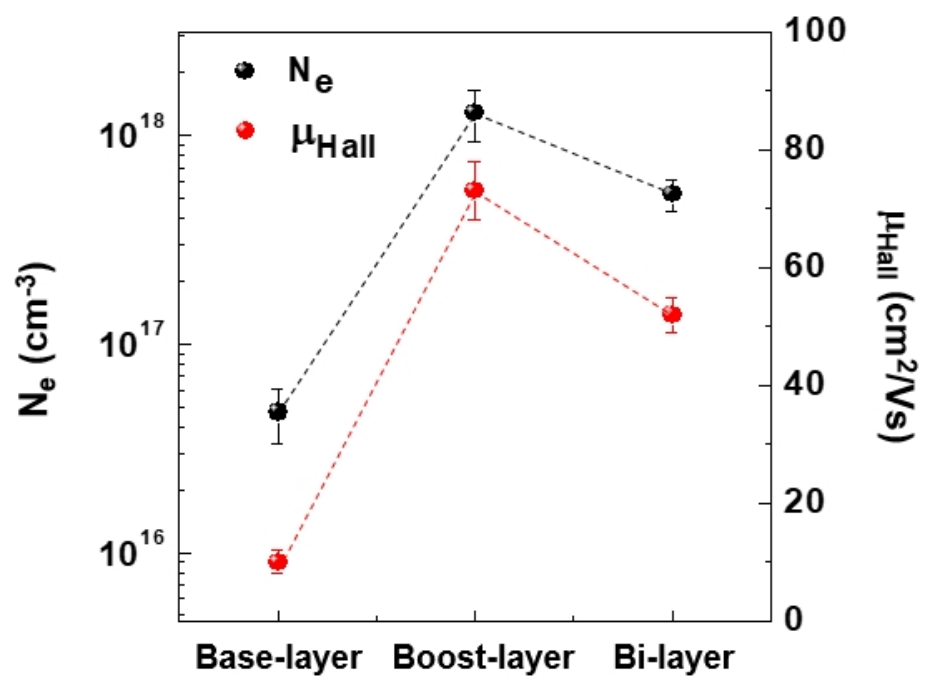

Figure S2. Carrier density $\left(N_{e}\right)$ and Hall mobility $\left(\mu_{\text {Hall }}\right)$ of the ALD-derived base layer, boost layer and bilayer IGZO thin films at $T_{A}=500{ }^{\circ} \mathrm{C}$ on the glass substrate.

Table S1. $N_{e}$ and $\mu_{\text {Hall }}$ of the ALD-derived base layer, boost layer and bilayer IGZO thin films at $T_{A}=$ $500{ }^{\circ} \mathrm{C}$ on a glass substrate.

\begin{tabular}{ccc}
\hline Material & $N_{e}\left[10^{17} / \mathrm{cm}^{3}\right]$ & $\mu_{\text {Hall }}\left[\mathrm{cm}^{2} /(\mathrm{V} \mathrm{s})\right]$ \\
\hline $\mathrm{In}_{0.52} \mathrm{Ga}_{0.29} \mathrm{Zn}_{0.19} \mathrm{O}(13 \mathrm{~nm})$, Base layer & $0.47 \pm 0.14$ & $10 \pm 2$ \\
$\mathrm{In}_{0.82} \mathrm{Ga}_{0.08} \mathrm{Zn}_{0.10} \mathrm{O}(13 \mathrm{~nm})$, Boost layer & $12.81 \pm 3.49$ & $73 \pm 5$ \\
$\mathrm{In}_{0.82} \mathrm{Ga}_{0.08} \mathrm{Zn}_{0.10} \mathrm{O}(3 \mathrm{~nm}) / \mathrm{In}_{0.52} \mathrm{Ga}_{0.29} \mathrm{Zn}_{0.19} \mathrm{O}(10 \mathrm{~nm})$, Bilayer & $5.24 \pm 0.91$ & $52 \pm 3$ \\
\hline
\end{tabular}



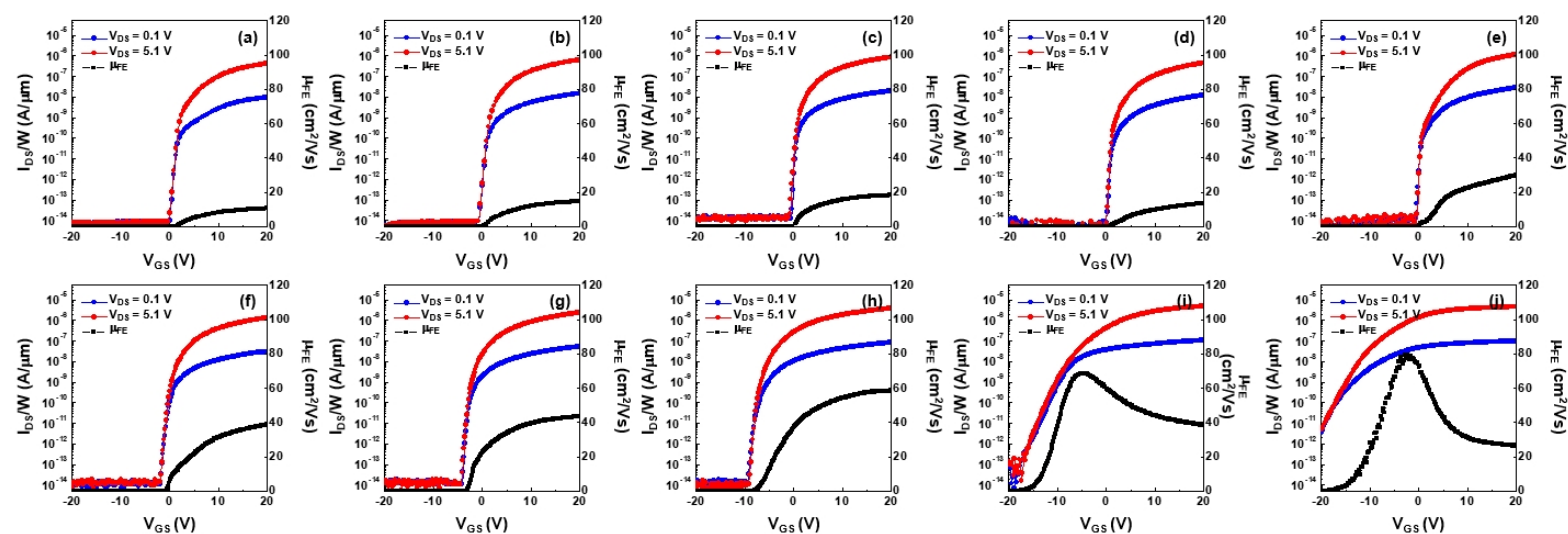

Figure S3. Representative transfer characteristics of ALD-derived IGZO bottom-gate structure TFT with 10 different cation compositions; (a) $\operatorname{In}_{0.42} \mathrm{Ga}_{0.48} \mathrm{Zn}_{0.10} \mathrm{O}$, (b) $\operatorname{In}_{0.47} \mathrm{Ga}_{0.40} \mathrm{Zn}_{0.13} \mathrm{O}$, (c) $\mathrm{In}_{0.52} \mathrm{Ga}_{0.29} \mathrm{Zn}_{0.19} \mathrm{O}$, (d) $\operatorname{In}_{0.28} \mathrm{Ga}_{0.30} \mathrm{Zn}_{0.42} \mathrm{O}$, (e) $\operatorname{In}_{0.32} \mathrm{Ga}_{0.21} \mathrm{Zn}_{0.47} \mathrm{O}$, (f) $\operatorname{In}_{0.42} \mathrm{Ga}_{0.48} \mathrm{Zn}_{0.10} \mathrm{O}$, (g) $\mathrm{In}_{0.42} \mathrm{Ga}_{0.15} \mathrm{Zn}_{0.43} \mathrm{O}$, (h) $\mathrm{In}_{0.54} \mathrm{Ga}_{0.12} \mathrm{Zn}_{0.34} \mathrm{O}$, (i) $\operatorname{In}_{0.67} \mathrm{Ga}_{0.10} \mathrm{Zn}_{0.22} \mathrm{O}$, and (j) $\mathrm{In}_{0.82} \mathrm{Ga}_{0.08} \mathrm{Zn}_{0.10} \mathrm{O}$. The devices were fabricated on the $\mathrm{SiO}_{2} / \mathrm{Si}$ substrate where the thermal $\mathrm{SiO}_{2}$ and $\mathrm{p}^{+}-\mathrm{Si}$ substrate act as the gate insulator and electrode, respectively.

Table S2. Summary of electrical parameters: $\mu_{F E}, S S, V_{T H}$, and $I_{O N / O F F}$ of the ALD-derived IGZO bottom-gate structure TFTs with 10 different cation compositions.

\begin{tabular}{|c|c|c|c|c|c|c|c|}
\hline Channel & $\begin{array}{c}\text { Gate } \\
\text { Insulator }\end{array}$ & $\begin{array}{c}\text { Cation } \\
\text { Composition } \\
{[\text { In:Ga:Zn, at\%] }}\end{array}$ & $\begin{array}{c}\mu_{F E} \\
{\left[\mathrm{~cm}^{2} /(\mathrm{V} \mathrm{s})\right]}\end{array}$ & $\begin{array}{c}S S \\
{[\mathrm{~V} / \mathrm{dec}]}\end{array}$ & $\begin{array}{l}V_{T H} \\
{[\mathrm{~V}]}\end{array}$ & $\begin{array}{l}I_{O N / O F F} \\
{\left[\times 10^{7}\right]}\end{array}$ & $\begin{array}{l}\text { Corresponding } \\
\text { I-V curve } \\
\text { in Fig. S2 }\end{array}$ \\
\hline \multirow{10}{*}{ IGZO } & \multirow{10}{*}{$\begin{array}{c}100 \mathrm{~nm} \\
\mathrm{SiO}_{2}\end{array}$} & $42: 48: 10$ & 10.6 & 0.37 & 1.58 & $\sim 5.4$ & (a) \\
\hline & & $47: 40: 13$ & 14.5 & 0.40 & 1.05 & $\sim 7.2$ & (b) \\
\hline & & $52: 29: 19$ & 18.2 & 0.43 & 0.57 & $\sim 8.3$ & (c) \\
\hline & & $28: 30: 42$ & 13.7 & 0.34 & 1.35 & $\sim 6.8$ & (d) \\
\hline & & $32: 21: 47$ & 29.8 & 0.42 & 0.92 & $\sim 13.3$ & (e) \\
\hline & & $38: 18: 44$ & 38.5 & 0.52 & -0.24 & $\sim 17.7$ & (f) \\
\hline & & $42: 15: 43$ & 43.5 & 0.60 & -2.69 & $\sim 19.5$ & (g) \\
\hline & & $54: 12: 34$ & 58.6 & 0.71 & -7.32 & $\sim 31.2$ & (h) \\
\hline & & $67: 10: 22$ & 68.7 & 1.72 & -11.68 & $\sim 3.8$ & (i) \\
\hline & & $82: 8: 10$ & 79.4 & 2.63 & -16.44 & $\sim 0.01$ & (j) \\
\hline
\end{tabular}



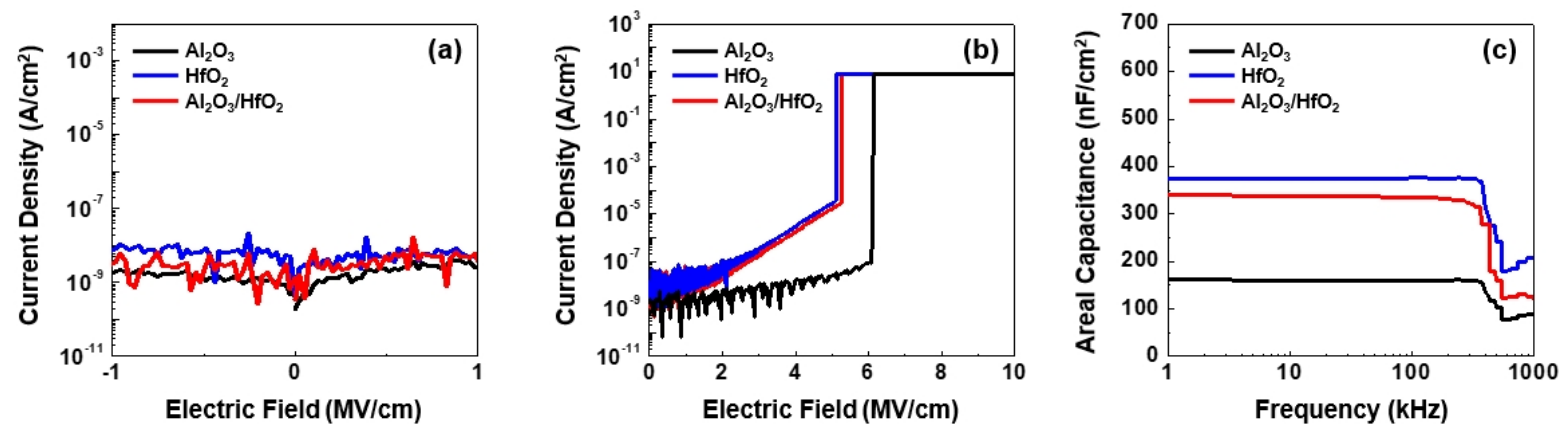

Figure S4. Electrical characteristics of the ALD-derived high- $\kappa$ dielectric film with an $\mathrm{Al}_{2} \mathrm{O}_{3}(50 \mathrm{~nm})$, $\mathrm{HfO}_{2}(50 \mathrm{~nm})$ and $\mathrm{Al}_{2} \mathrm{O}_{3}(4 \mathrm{~nm}) / \mathrm{HfO}_{2}(50 \mathrm{~nm})$ stack: (a) leakage current density $\left(J_{g}\right)$, (b) breakdown field $\left(E_{b r}\right)$, and (c) frequency-dependent areal capacitance.

The leakage current density $\left(J_{g}\right)$, critical breakdown field $\left(E_{b r}\right)$ and dielectric constant $(\kappa)$ of the MIM capacitors with different ALD-derived high- $\kappa$ dielectric films were measured to evaluate their suitability as a gate insulator for IGZO TFTs. The fabricated MIM capacitors were subjected to PDA at $400^{\circ} \mathrm{C}$ in a vacuum ambient. Figure $\mathbf{S 4 a}$ shows the variations of the leakage current density $\left(J_{g}\right)$ as a function of the applied electric field $(E)$, which was thickness-normalized for better comparison. The capacitor with an $\mathrm{Al}_{2} \mathrm{O}_{3}$ film had a $J_{g}$ value of $2.37 \times 10^{-9} \mathrm{~A} / \mathrm{cm}^{2}$ at $1 \mathrm{MV} / \mathrm{cm}$. The $J_{g}$ value slightly increased to $5.55 \times 10^{-9} \mathrm{~A} / \mathrm{cm}^{2}$ for the capacitor with the $\mathrm{HfO}_{2}$ film. This phenomenon can be attributed to the existence of the grain boundary defects in $\mathrm{HfO}_{2}$ as a leakage current path (Figure S10). Since the $\mathrm{IGZO} / \mathrm{HfO}_{2}$ interface is known to be inferior to the $\mathrm{IGZO} / \mathrm{SiO}_{2}$ and $\mathrm{IGZO} / \mathrm{Al}_{2} \mathrm{O}_{3}$, the 4-nm-thick $\mathrm{Al}_{2} \mathrm{O}_{3}$ film was inserted as the interface stabilizer. The capacitor with an $\mathrm{Al}_{2} \mathrm{O}_{3} / \mathrm{HfO}_{2}$ dielectric stack film had a $J_{g}$ value of $3.59 \times 10^{-9} \mathrm{~A} / \mathrm{cm}^{2}$, which is an intermediate value between the $J_{g}$ value of $\mathrm{Al}_{2} \mathrm{O}_{3}$ and $\mathrm{HfO}_{2}$ film, indicating that the inserted $\mathrm{Al}_{2} \mathrm{O}_{3}$ thin film can suppress the leakage current. The $E_{b r}$ value, which is defined as the electric field yielding a rapid increase up to the compliance limit, is also shown in Figure S4b. The $E_{b r}$ value for the different ALD-derived high- $\kappa$ dielectric films shows the same trend as the $J_{g}$ value. Figure $\mathbf{S 4 c}$ shows the variations in the areal capacitance value as a function of applied frequency for the MIM capacitors with different ALD-derived high- $\kappa$ dielectric films. The areal capacitance values of the MIM capacitors with the $\mathrm{Al}_{2} \mathrm{O}_{3}, \mathrm{HfO}_{2}$, and $\mathrm{Al}_{2} \mathrm{O}_{3} / \mathrm{HfO}_{2}$ dielectric stack films were $175.1,375.8$, and $334.9 \mathrm{nF} / \mathrm{cm}^{2}$ at $100 \mathrm{kHz}$, respectively. From these values, the $\kappa$ values were calculated to be 9,21 , and 20 , respectively. It is evident that the $\mathrm{Al}_{2} \mathrm{O}_{3} / \mathrm{HfO}_{2}$ dielectric stack film with the inserted 4-nm-thick $\mathrm{Al}_{2} \mathrm{O}_{3}$ thin layer had better $J_{g}$ and $E_{b r}$ values compared to the $\mathrm{HfO}_{2}$ only capacitor, whereas $\kappa$ values of 20 were obtained that are comparable to that of the $\mathrm{HfO}_{2}$ only capacitor. 
The $J_{g}, E_{b r}$, and $\kappa$ values for different ALD-derived high- $\kappa$ dielectric films are summarized in Table S3.

Table S3. Summary of electrical parameters: leakage current density $\left(J_{g}\right)$, critical breakdown field $\left(E_{b r}\right)$, areal capacitance $\left(C_{\mathrm{OX}}\right)$, and $\kappa$ values of the ALD-derived high- $\kappa$ dielectric films.

\begin{tabular}{|c|c|c|c|c|c|}
\hline Material & $\begin{array}{l}\text { Thickness } \\
{[\mathrm{nm}]}\end{array}$ & $\begin{array}{c}J_{g} \\
{\left[\mathrm{~A} / \mathrm{cm}^{2}\right]} \\
(@ 1 \mathrm{MV} / \mathrm{cm})\end{array}$ & $\begin{array}{c}E_{b r} \\
{[\mathrm{MV} / \mathrm{cm}]}\end{array}$ & $\begin{array}{c}C_{O X} \\
{\left[\mathrm{nF} / \mathrm{cm}^{2}\right]} \\
(@ 100 \mathrm{kHz})\end{array}$ & $\begin{array}{c}\kappa \\
(@ 100 \mathrm{kHz})\end{array}$ \\
\hline $\mathrm{Al}_{2} \mathrm{O}_{3}$ & 50 & $2.37 \times 10^{-9}$ & 6.1 & 159.31 & $\sim 9$ \\
\hline $\mathrm{HfO}_{2}$ & 50 & $5.55 \times 10^{-9}$ & 5.1 & 375.80 & $\sim 21$ \\
\hline $\mathrm{Al}_{2} \mathrm{O}_{3} / \mathrm{HfO}_{2}$ & $\begin{array}{c}54 \\
\left(\mathrm{Al}_{2} \mathrm{O}_{3}=4, \mathrm{HfO}_{2}=50\right)\end{array}$ & $3.59 \times 10^{-9}$ & 5.3 & 334.91 & $\sim 20$ \\
\hline
\end{tabular}



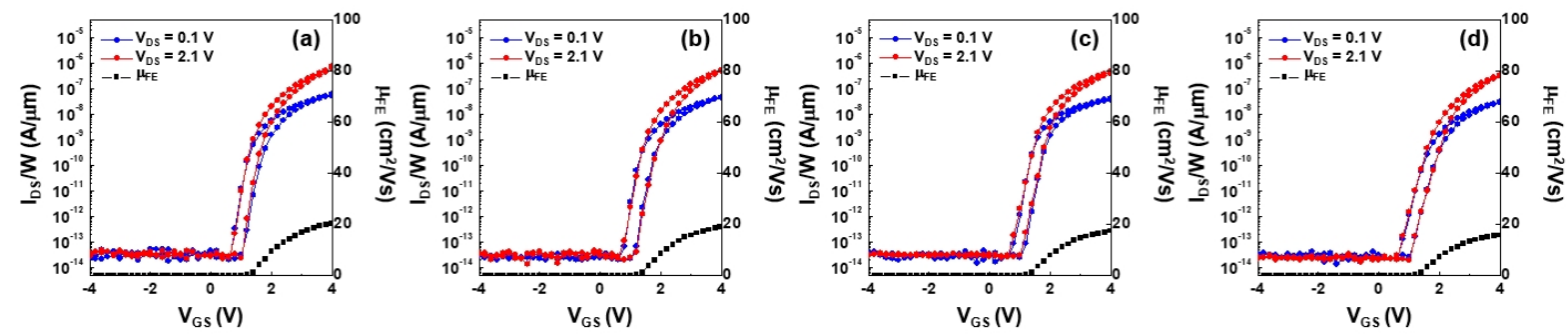

Figure S5. Representative transfer characteristics of the base layer IGZO TFTs with different thicknesses of $\mathrm{HfO}_{2}$ as a gate insulator; (a) 60, (b) 70, (c) 80, and (d) $90 \mathrm{~nm}$.

Table S4. Summary of electrical parameters: $\mu_{F E}, S S, V_{T H}, I_{O N / O F F}$, and $N_{T \cdot \max }$ of the base layer IGZO TFTs with different thickness of $\mathrm{HfO}_{2}$ as a gate insulator.

\begin{tabular}{|c|c|c|c|c|c|c|c|}
\hline Channel & $\begin{array}{c}\text { Gate } \\
\text { Insulator. }\end{array}$ & $\begin{array}{c}C_{O X} \\
{\left[\mathrm{nF} / \mathrm{cm}^{2}\right]}\end{array}$ & $\begin{array}{c}\mu_{F E} \\
{\left[\mathrm{~cm}^{2} /(\mathrm{V} \mathrm{s})\right]}\end{array}$ & $\begin{array}{c}S S \\
{[\mathrm{~V} / \mathrm{dec}]}\end{array}$ & $\begin{array}{l}V_{T H} \\
{[\mathrm{~V}]}\end{array}$ & $\begin{array}{l}I_{\text {ON/OFF }} \\
{\left[\times 10^{7}\right]}\end{array}$ & $\begin{array}{c}N_{T, \max } \\
{\left[\mathrm{cm}^{-3} \mathrm{ev}^{-1}\right]}\end{array}$ \\
\hline \multirow{4}{*}{$\begin{array}{c}\mathrm{In}_{0.52} \mathrm{Ga}_{0.29} \mathrm{Zn}_{0.19} \mathrm{O} \\
\text { (Base layer) }\end{array}$} & $\begin{array}{l}60 \mathrm{~nm} \\
\mathrm{HfO}_{2}\end{array}$ & 313 & $20.5 \pm 0.38$ & $0.15 \pm 0.01$ & $1.27 \pm 0.25$ & $\sim 2.2$ & $3.96 \times 10^{18}$ \\
\hline & $\begin{array}{l}70 \mathrm{~nm} \\
\mathrm{HfO}_{2}\end{array}$ & 269 & $18.9 \pm 0.45$ & $0.17 \pm 0.02$ & $1.38 \pm 0.31$ & $\sim 1.5$ & $3.97 \times 10^{18}$ \\
\hline & $\begin{array}{l}80 \mathrm{~nm} \\
\mathrm{HfO}_{2}\end{array}$ & 234 & $17.4 \pm 0.56$ & $0.20 \pm 0.02$ & $1.47 \pm 0.29$ & $\sim 1.4$ & $3.96 \times 10^{18}$ \\
\hline & $\begin{array}{l}90 \mathrm{~nm} \\
\mathrm{HfO}_{2}\end{array}$ & 208 & $15.6 \pm 0.31$ & $0.24 \pm 0.01$ & $1.61 \pm 0.21$ & $\sim 1.2$ & $4.00 \times 10^{18}$ \\
\hline
\end{tabular}
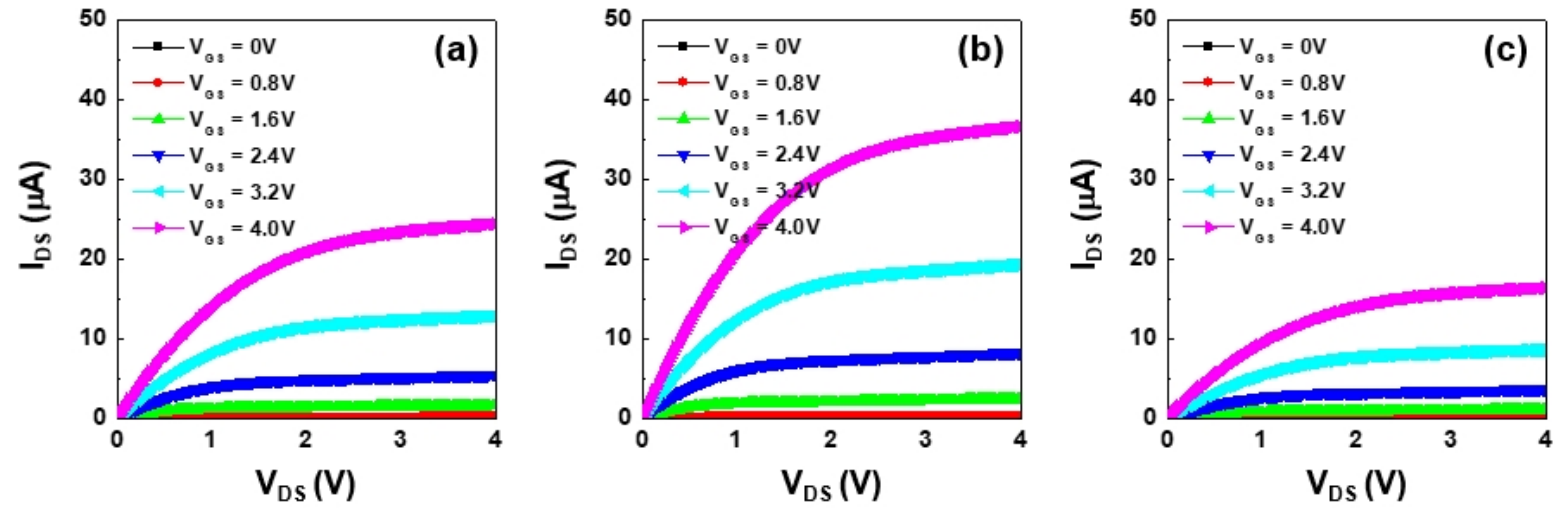

Figure S6. Corresponding output characteristics of the base layer IGZO TFT with different gate insulators of (a) $\mathrm{HfO}_{2}(100 \mathrm{~nm})$, (b) $\mathrm{HfO}_{2}(50 \mathrm{~nm})$, and (c) $\mathrm{Al}_{2} \mathrm{O}_{3}(50 \mathrm{~nm})$. 

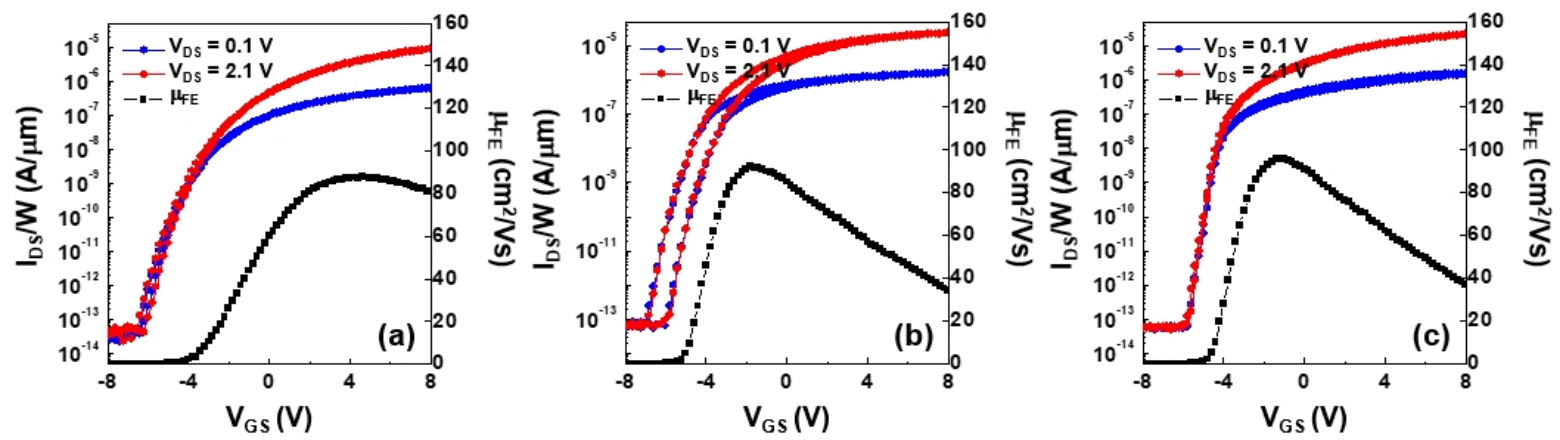

Figure S7. Representative transfer characteristics of the boost layer IGZO TFTs with different gate insulators of (a) $\mathrm{Al}_{2} \mathrm{O}_{3}(50 \mathrm{~nm})$, (b) $\mathrm{HfO}_{2}(50 \mathrm{~nm})$, and (c) $\mathrm{Al}_{2} \mathrm{O}_{3}(4 \mathrm{~nm}) / \mathrm{HfO}_{2}(50 \mathrm{~nm})$.

Table S5. Summary of electrical parameters: $\mu_{F E}, S S, V_{T H}, I_{O N / O F F}$, and $N_{T \cdot m a x}$ for the boost layer IGZO TFTs with different gate insulators of (a) $\mathrm{Al}_{2} \mathrm{O}_{3}$ (50-nm), (b) $\mathrm{HfO}_{2}(50-\mathrm{nm})$, and (c) $\mathrm{Al}_{2} \mathrm{O}_{3}$ (4-nm)/ $\mathrm{HfO}_{2}$ (50-nm).

\begin{tabular}{|c|c|c|c|c|c|c|c|}
\hline Channel & $\begin{array}{l}\text { Gate } \\
\text { Insulator }\end{array}$ & $\begin{array}{c}C_{O X} \\
{\left[\mathrm{nF} / \mathrm{cm}^{2}\right]}\end{array}$ & $\begin{array}{c}\mu_{F E} \\
{\left[\mathrm{~cm}^{2} /(\mathrm{V} \mathrm{s})\right]}\end{array}$ & $\begin{array}{c}S S \\
{[\mathrm{~V} / \mathrm{dec}]}\end{array}$ & $\begin{array}{l}V_{T H} \\
{[\mathrm{~V}]}\end{array}$ & $\begin{array}{l}I_{O N / O F F} \\
{\left[\times 10^{7}\right]}\end{array}$ & $\begin{array}{c}N_{T, \max } \\
{\left[\mathrm{cm}^{-3} \mathrm{ev}^{-1}\right]}\end{array}$ \\
\hline \multirow{3}{*}{$\begin{array}{c}\mathrm{In}_{0.82} \mathrm{Ga}_{0.08} \mathrm{Zn}_{0.10} \mathrm{O} \\
\text { (Boost layer) }\end{array}$} & $\begin{array}{l}50 \mathrm{~nm} \\
\mathrm{Al}_{2} \mathrm{O}_{3}\end{array}$ & 159 & $87.8 \pm 0.73$ & $0.63 \pm 0.02$ & $-4.36 \pm 0.22$ & $\sim 17.8$ & $8.08 \times 10^{18}$ \\
\hline & $\begin{array}{l}50 \mathrm{~nm} \\
\mathrm{HfO}_{2}\end{array}$ & 376 & $92.3 \pm 0.73$ & $0.36 \pm 0.03$ & $-5.58 \pm 0.28$ & $\sim 35.0$ & $10.9 \times 10^{18}$ \\
\hline & $\begin{array}{c}54 \mathrm{~nm} \\
\mathrm{Al}_{2} \mathrm{O}_{3} / \mathrm{HfO}_{2}\end{array}$ & 335 & $95.7 \pm 0.66$ & $0.30 \pm 0.02$ & $-4.84 \pm 0.14$ & $\sim 37.4$ & $8.10 \times 10^{18}$ \\
\hline
\end{tabular}
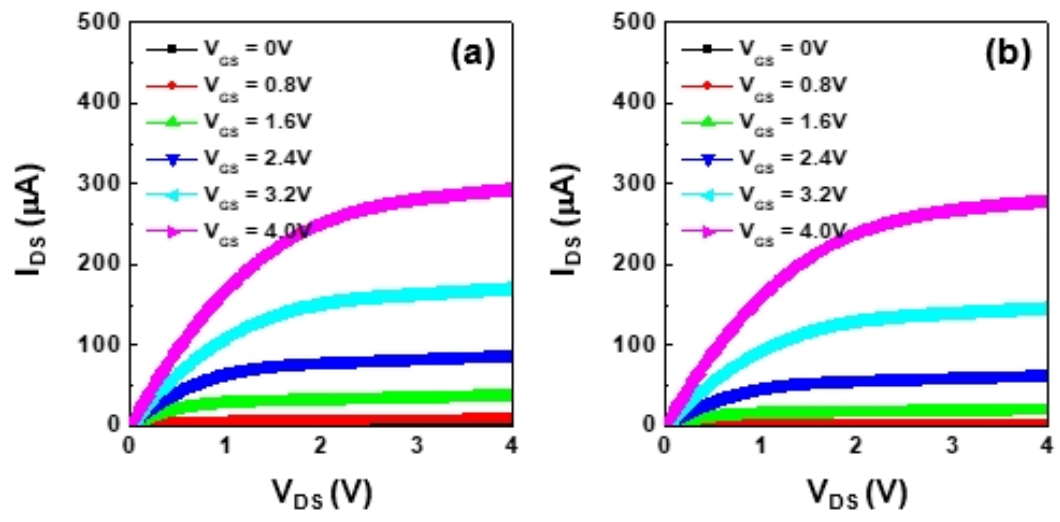

Figure S8. Corresponding output characteristics of the bilayer IGZO TFTs with different gate insulators of (a) $\mathrm{HfO}_{2}(50 \mathrm{~nm})$ and (b) $\mathrm{Al}_{2} \mathrm{O}_{3}(4 \mathrm{~nm}) / \mathrm{HfO}_{2}(50 \mathrm{~nm})$. 
(a)

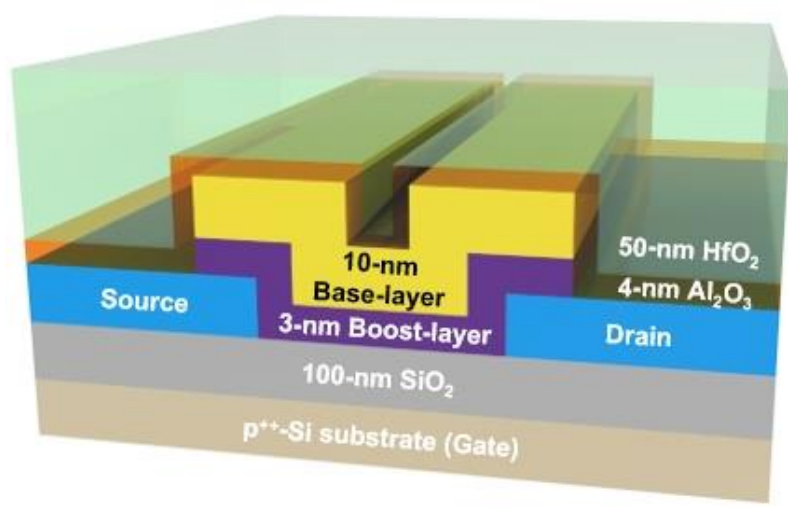

(b)

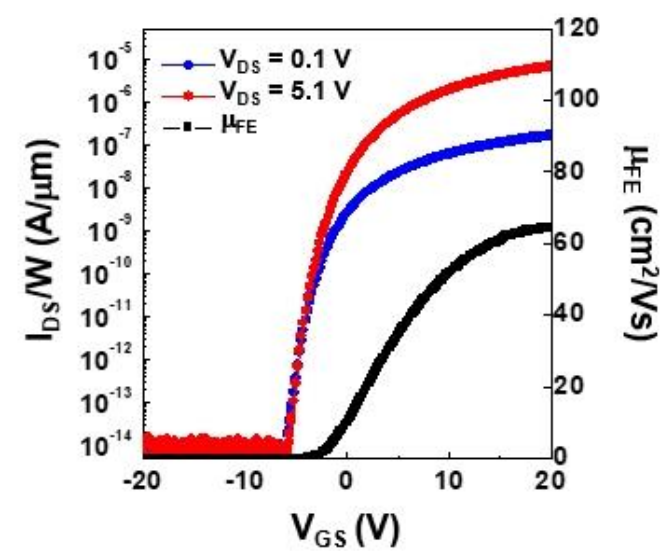

Figure S9. (a) Schematic diagram of the bottom gate structure bilayer IGZO TFT with gate insulator of $\mathrm{SiO}_{2}(100 \mathrm{~nm})$ and (b) corresponding transfer characteristic. The device went through PDA at $500^{\circ} \mathrm{C}$ for $1 \mathrm{~h}$ in air ambient.

Table S6. Summary of electrical parameters: $\mu_{F E}, S S$, and $V_{T H}$, and $I_{O N / O F F}$ of the bilayer IGZO TFT with gate insulator of $\mathrm{SiO}_{2}(100 \mathrm{~nm})$ through $\mathrm{PDA}$ at $500^{\circ} \mathrm{C}$ for $1 \mathrm{~h}$ in air ambient.

\begin{tabular}{cccccccc}
\hline Channel & $\begin{array}{c}\text { Gate } \\
\text { Insulator }\end{array}$ & $\begin{array}{c}C_{O X} \\
{\left[\mathrm{nF} / \mathrm{cm}^{2}\right]}\end{array}$ & $\begin{array}{c}\mu_{F E} \\
{\left[\mathrm{~cm}^{2} /(\mathrm{V} \mathrm{s})\right]}\end{array}$ & $\begin{array}{c}S S \\
{[\mathrm{~V} / \mathrm{dec}]}\end{array}$ & $\begin{array}{c}V_{T H} \\
{[\mathrm{~V}]}\end{array}$ & $\begin{array}{c}I_{\text {ON/OFF }} \\
{\left[\times 10^{7}\right]}\end{array}$ & $\begin{array}{c}N_{T, \text { max }} \\
{\left[\mathrm{cm}^{-3} \mathrm{eV}^{-1}\right]}\end{array}$ \\
\hline \hline $\begin{array}{c}\mathrm{In}_{0.60} \mathrm{Ga}_{0.21} \mathrm{Zn}_{0.19} \mathrm{O} \\
(\text { Bilayer })\end{array}$ & $\begin{array}{c}100 \mathrm{~nm} \\
\mathrm{SiO}_{2}\end{array}$ & 34.5 & $64.6 \pm 1.21$ & $0.79 \pm 0.01$ & $-3.80 \pm 1.02$ & $\sim 22.1$ & $2.21 \times 10^{18}$ \\
\hline
\end{tabular}



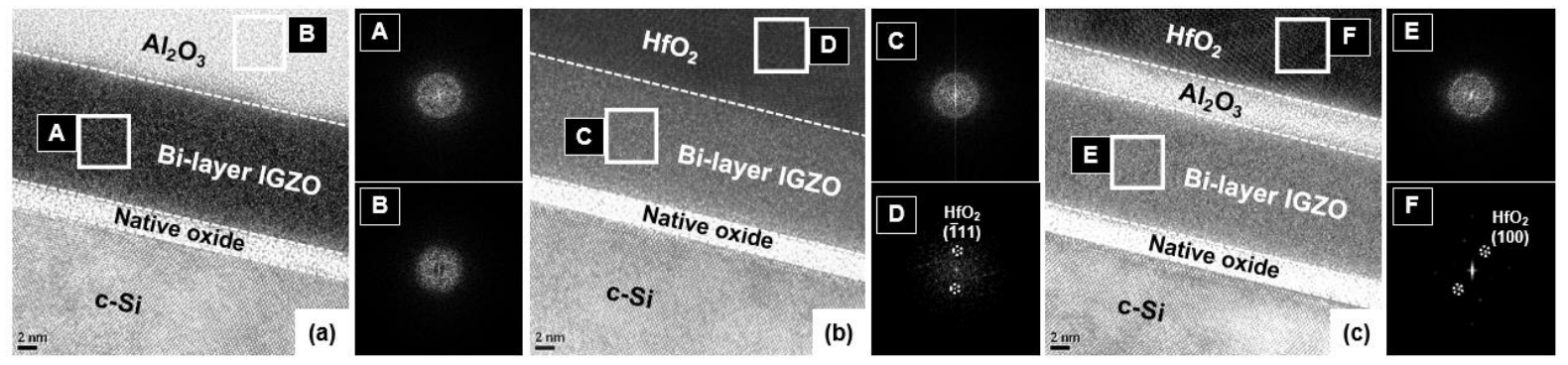

Figure S10. Cross-sectional HRTEM images of (a) $\mathrm{Al}_{2} \mathrm{O}_{3}$ /bilayer IGZO, (b) $\mathrm{HfO}_{2} /$ bilayer IGZO and (c) $\mathrm{HfO}_{2} / \mathrm{Al}_{2} \mathrm{O}_{3} /$ bilayer IGZO. Fast Fourier transform (FFT) patterns of the selected area in IGZO film are inserted in the given TEM images.

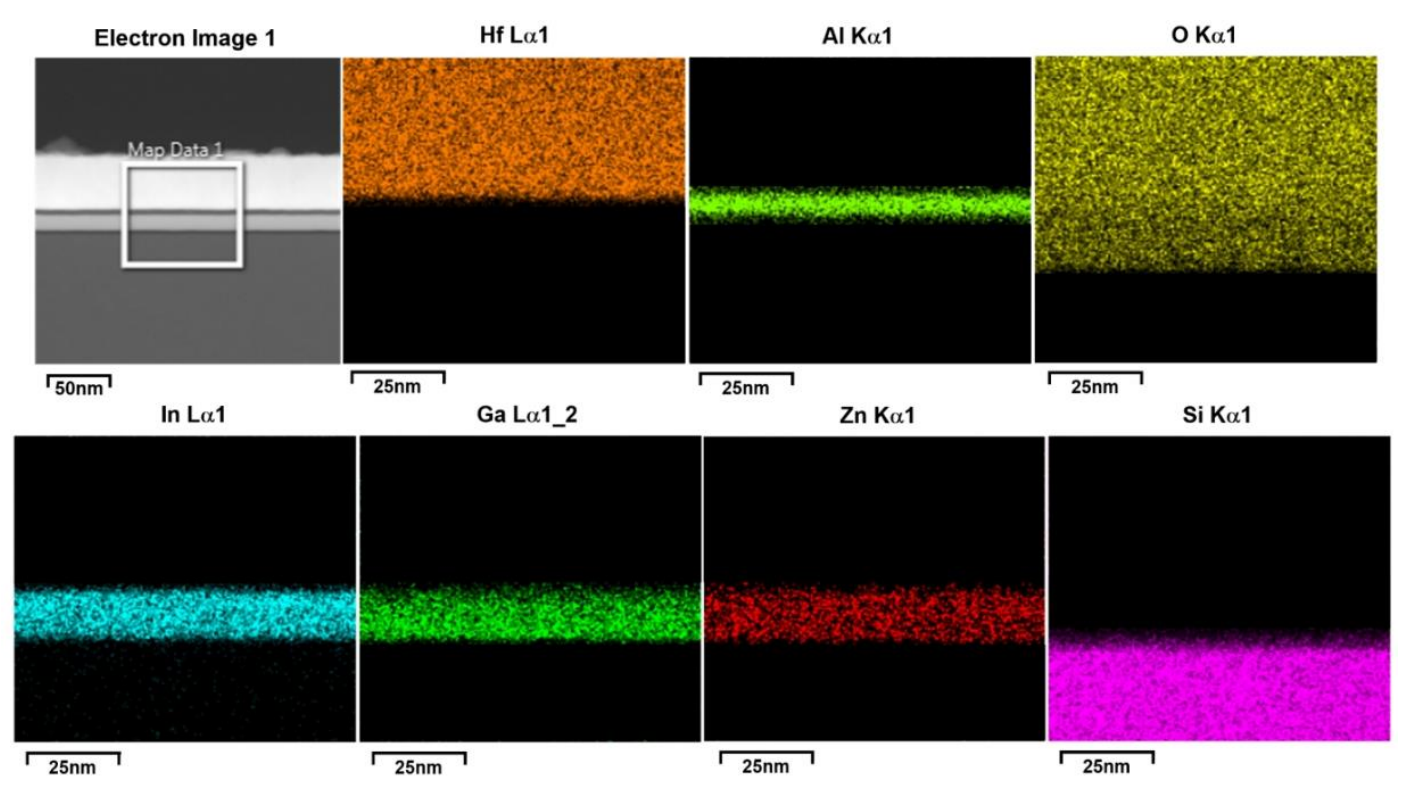

Figure S11. Elemental distributions of the $\mathrm{HfO}_{2} / \mathrm{Al}_{2} \mathrm{O}_{3}$ /bilayer IGZO stack by energy dispersive spectroscopy (EDS) mapping. 

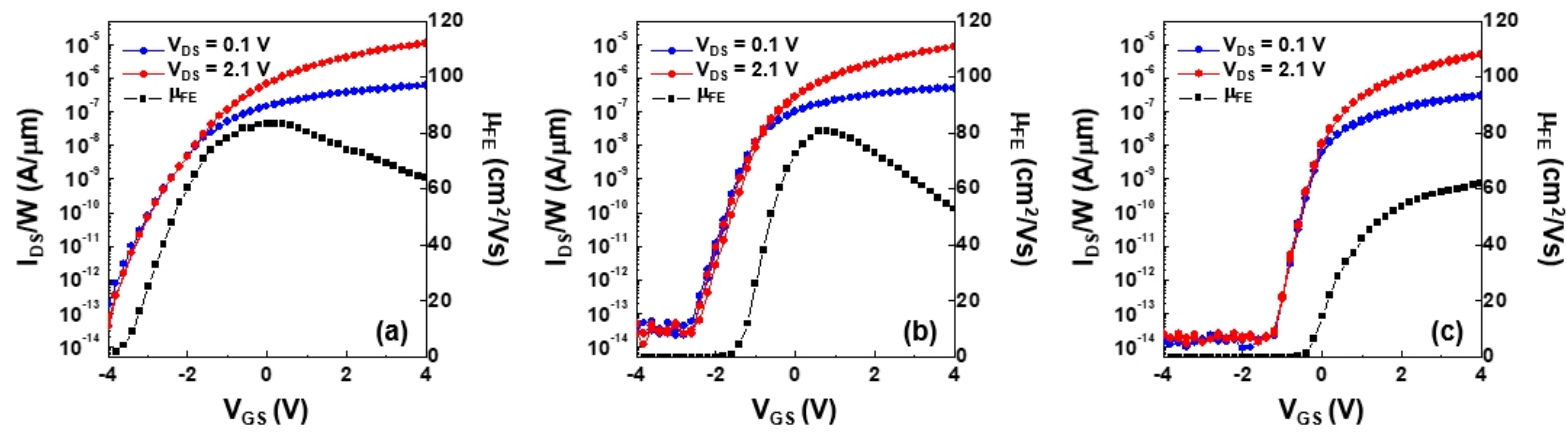

Figure S12. Representative transfer characteristics of the bilayer IGZO TFT with gate insulator of $\mathrm{Al}_{2} \mathrm{O}_{3}(4 \mathrm{~nm}) / \mathrm{HfO}_{2}(50 \mathrm{~nm})$ stack varying PDA conditions; PDA at (a) $300^{\circ} \mathrm{C}$, (b) $400^{\circ} \mathrm{C}$ for $1 \mathrm{~h}$ in air, and (c) $400^{\circ} \mathrm{C}$ for $1 \mathrm{~h}$ in $\mathrm{O}_{2}$ ambient.

Table S7. Summary of electrical parameters: $\mu_{F E}, S S, V_{T H}$, and $I_{O N / O F F}$, and $N_{T, \max }$ of the bilayer IGZO TFTs with gate insulator of $\mathrm{Al}_{2} \mathrm{O}_{3}(4 \mathrm{~nm}) / \mathrm{HfO}_{2}(50 \mathrm{~nm})$ with varying PDA conditions.

\begin{tabular}{|c|c|c|c|c|c|c|c|}
\hline Channel & $\begin{array}{l}\text { Gate } \\
\text { Insulator }\end{array}$ & $\begin{array}{c}\text { PDA } \\
\text { Condition }\end{array}$ & $\begin{array}{c}\mu_{F E} \\
{\left[\mathrm{~cm}^{2} /(\mathrm{V} \mathrm{s})\right]}\end{array}$ & $\begin{array}{c}S S \\
{[\mathrm{~V} / \mathrm{dec}]}\end{array}$ & $\begin{array}{l}V_{T H} \\
{[\mathrm{~V}]}\end{array}$ & $\begin{array}{l}I_{O N / O F F} \\
{\left[\times 10^{7}\right]}\end{array}$ & $\begin{array}{c}N_{T, \max } \\
{\left[\mathrm{cm}^{-3} \mathrm{ev}^{-1}\right]}\end{array}$ \\
\hline \multirow{3}{*}{$\begin{array}{c}\operatorname{In}_{0.60} \mathrm{Ga}_{0.21} \mathrm{Zn}_{0.19} \mathrm{O} \\
\text { (Bilayer) }\end{array}$} & \multirow{3}{*}{$\begin{array}{c}54 \mathrm{~nm} \\
\mathrm{Al}_{2} \mathrm{O}_{3} / \mathrm{HfO}_{2}\end{array}$} & $\begin{array}{c}300^{\circ} \mathrm{C} \\
1 \mathrm{~h} \text { in air }\end{array}$ & $83.5 \pm 1.03$ & $0.46 \pm 0.02$ & $-2.64 \pm 0.67$ & $\sim 26.6$ & $12.4 \times 10^{18}$ \\
\hline & & $\begin{array}{c}400^{\circ} \mathrm{C} \\
1 \mathrm{~h} \text { in air }\end{array}$ & $80.8 \pm 0.86$ & $0.30 \pm 0.02$ & $-1.49 \pm 0.42$ & $\sim 24.8$ & $8.10 \times 10^{18}$ \\
\hline & & $\begin{array}{c}400^{\circ} \mathrm{C} \\
1 \mathrm{~h} \text { in } \mathrm{O}_{2}\end{array}$ & $61.9 \pm 1.25$ & $0.20 \pm 0.01$ & $-0.38 \pm 0.14$ & $\sim 21.7$ & $5.40 \times 10^{18}$ \\
\hline
\end{tabular}



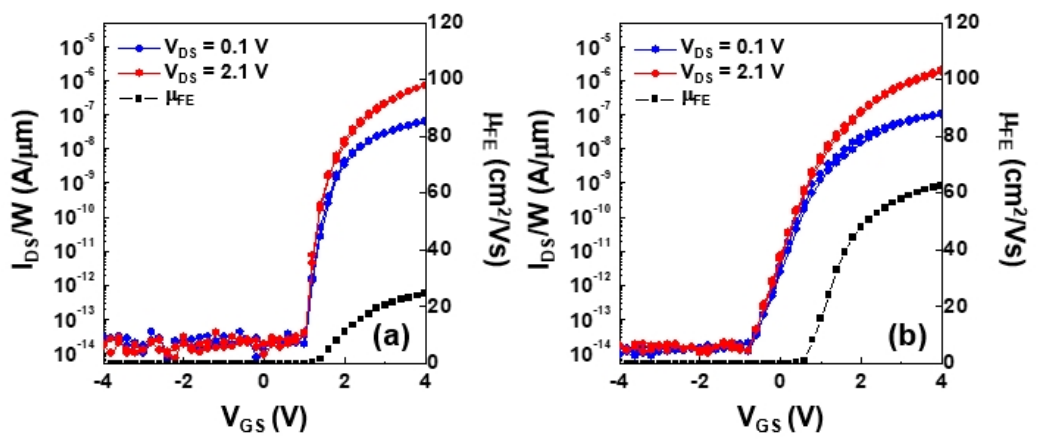

Figure S13. Representative transfer characteristics of the (a) base layer IGZO TFTs with the $\mathrm{Al}_{2} \mathrm{O}_{3}(4$ $\mathrm{nm}) / \mathrm{HfO}_{2}(50 \mathrm{~nm})$ gate insulator and (b) bilayer IGZO TFTs with a $\mathrm{Al}_{2} \mathrm{O}_{3}(50 \mathrm{~nm})$ gate insulator.

Table S8. Summary of electrical parameters: $\mu_{F E}, S S, V_{T H}, I_{O N / O F F}$, and $N_{T \cdot m a x}$ of the base layer IGZO TFTs with the $\mathrm{Al}_{2} \mathrm{O}_{3}(4 \mathrm{~nm}) / \mathrm{HfO}_{2}(50 \mathrm{~nm})$ and bilayer IGZO TFTs with $\mathrm{Al}_{2} \mathrm{O}_{3}(50 \mathrm{~nm})$ gate insulator.

\begin{tabular}{|c|c|c|c|c|c|c|c|}
\hline Channel & $\begin{array}{c}\text { Gate } \\
\text { Insulator }\end{array}$ & $\begin{array}{c}C_{O X} \\
{\left[\mathrm{nF} / \mathrm{cm}^{2}\right]}\end{array}$ & $\begin{array}{c}\mu_{F E} \\
{\left[\mathrm{~cm}^{2} /(\mathrm{V} \mathrm{s})\right]}\end{array}$ & $\begin{array}{c}S S \\
\text { [V/decade] }\end{array}$ & $\begin{array}{l}V_{T H} \\
{[\mathrm{~V}]}\end{array}$ & $\begin{array}{l}I_{\text {ON/OFF }} \\
{\left[\times 10^{7}\right]}\end{array}$ & $\begin{array}{c}N_{T, \max } \\
{\left[\mathrm{cm}^{-3} \mathrm{ev}^{-1}\right]}\end{array}$ \\
\hline $\begin{array}{l}\mathrm{In}_{0.52} \mathrm{Ga}_{0.29} \mathrm{Zn}_{0.19} \mathrm{O} \\
\text { (Base layer) }\end{array}$ & $\begin{array}{c}54 \mathrm{~nm} \\
\mathrm{Al}_{2} \mathrm{O}_{3} / \mathrm{HfO}_{2}\end{array}$ & 335 & $24.5 \pm 0.58$ & $0.10 \pm 0.01$ & $1.52 \pm 0.27$ & $\sim 3.8$ & $2.70 \times 10^{18}$ \\
\hline $\begin{array}{l}\mathrm{In}_{0.60} \mathrm{Ga}_{0.21} \mathrm{Zn}_{0.19} \mathrm{O} \\
\text { (Bilayer) }\end{array}$ & $\begin{array}{l}50 \mathrm{~nm} \\
\mathrm{Al}_{2} \mathrm{O}_{3}\end{array}$ & 159 & $62.7 \pm 0.81$ & $0.27 \pm 0.02$ & $0.74 \pm 0.13$ & $\sim 11.3$ & $3.46 \times 10^{18}$ \\
\hline
\end{tabular}



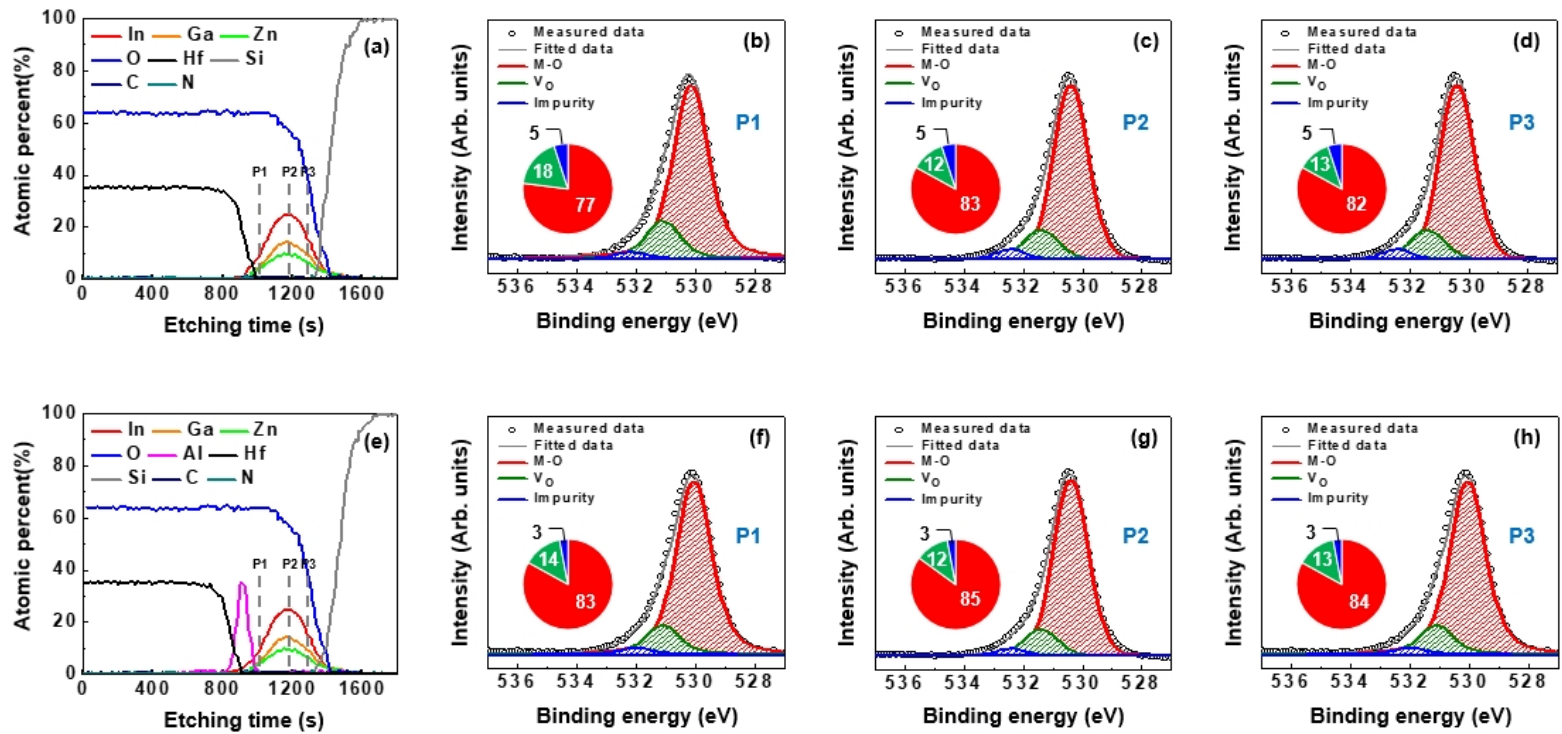

Figure S14. XPS depth profile of the base layer IGZO film with different high- $\kappa$ dielectric stacks and O $1 s$ spectra: (a) XPS depth profile of the $\mathrm{HfO}_{2}$ /base layer IGZO stack. O $1 s$ spectra taken from (b) $\mathrm{P} 1$, (c) P2, and (d) P3 position for the $\mathrm{HfO}_{2} /$ base layer IGZO stack. (e) XPS depth profile of the $\mathrm{HfO}_{2} / \mathrm{Al}_{2} \mathrm{O}_{3} /$ base layer IGZO stack. O $1 s$ spectra from (f) $\mathrm{P} 1$, (g) $\mathrm{P} 2$, and (h) P3 positions for the $\mathrm{HfO}_{2} / \mathrm{Al}_{2} \mathrm{O}_{3} /$ base layer IGZO stack.
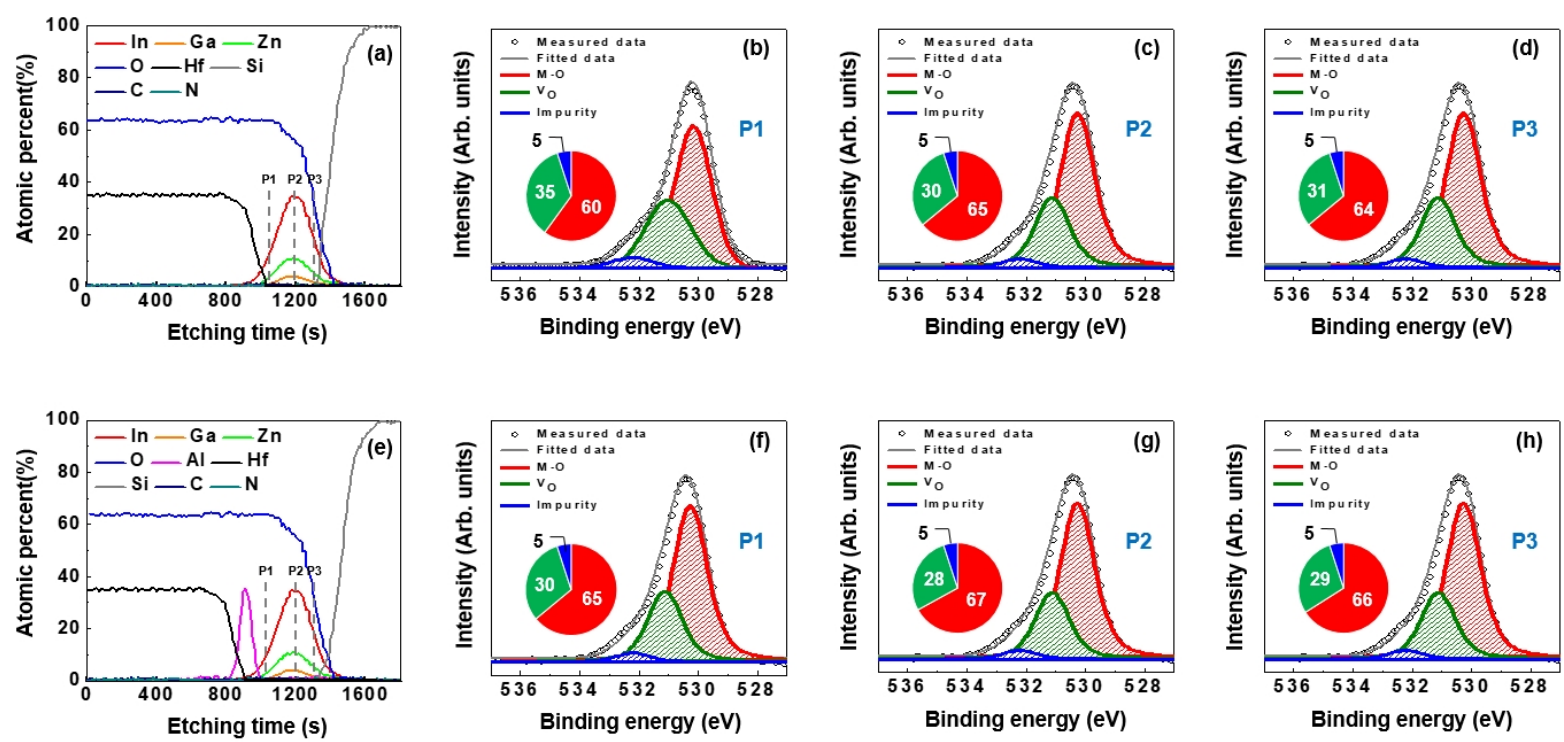

Figure S15. XPS depth profile of the boost layer IGZO film with different high- $\kappa$ dielectric stacks and O $1 s$ spectra: (a) XPS depth profile of the $\mathrm{HfO}_{2} /$ boost layer IGZO stack. O $1 s$ spectra taken from (b) P1, (c) P2, and (d) P3 position for the $\mathrm{HfO}_{2} /$ boost layer IGZO stack. (e) XPS depth profile of the $\mathrm{HfO}_{2} / \mathrm{Al}_{2} \mathrm{O}_{3} /$ boost layer IGZO stack. O $1 s$ spectra from (f) $\mathrm{P} 1$, (g) $\mathrm{P} 2$, and (h) $\mathrm{P} 3$ position for the $\mathrm{HfO}_{2} / \mathrm{Al}_{2} \mathrm{O}_{3} /$ boost layer IGZO stack. 
(a)

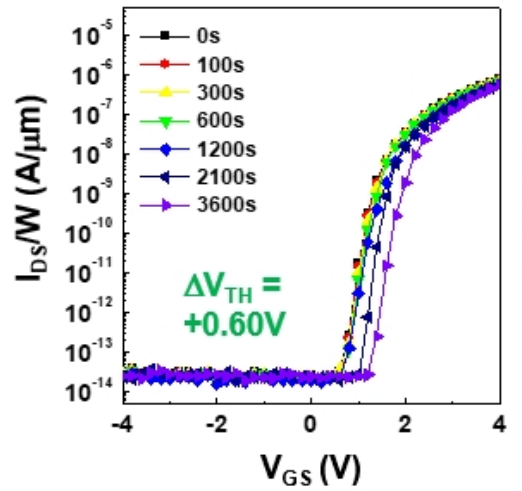

(d)

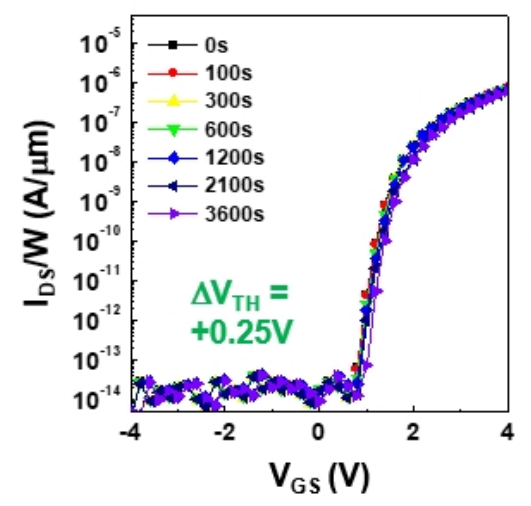

(b)

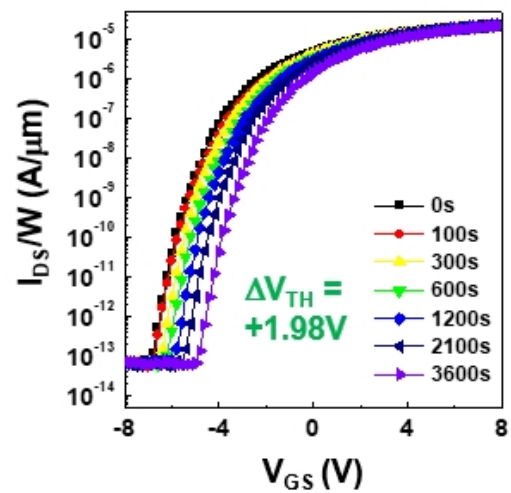

(e)

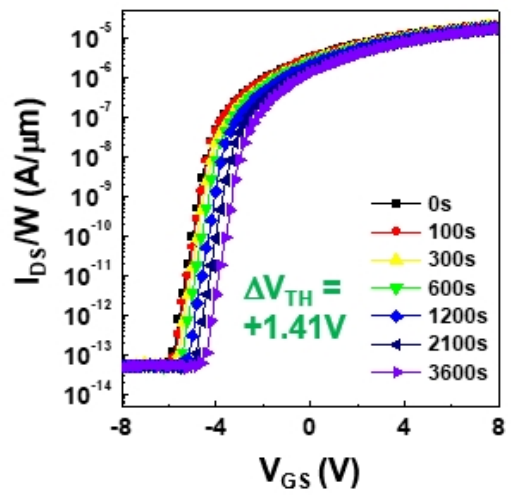

(c)

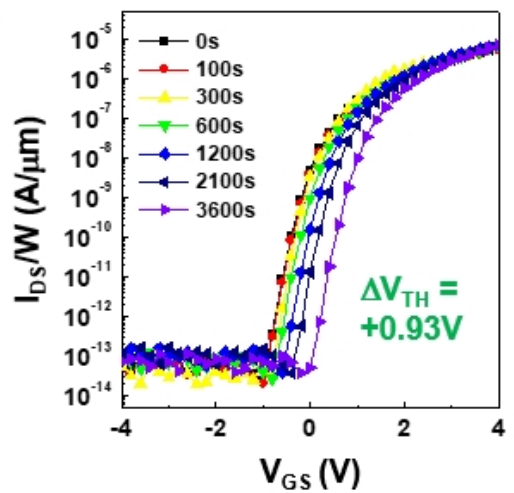

(f)

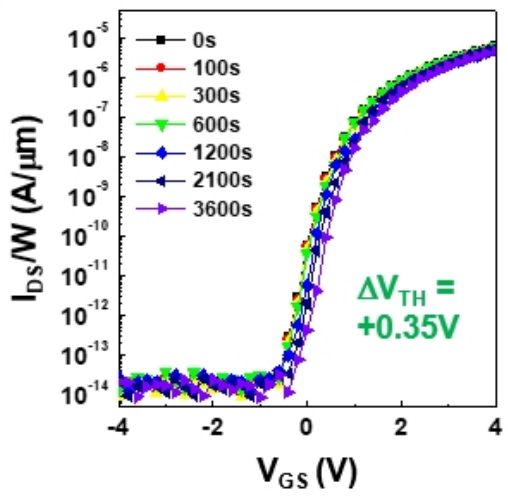

Figure S16. Evolution of time-dependent transfer characteristics of ALD-derived IGZO TFTs with various gate insulator; (a,d) base layer IGZO TFTs with (a) $\mathrm{HfO}_{2}$ and (d) $\mathrm{Al}_{2} \mathrm{O}_{3} / \mathrm{HfO}_{2}$, (b,e) boost layer IGZO TFTs with (b) $\mathrm{HfO}_{2}$ and (e) $\mathrm{Al}_{2} \mathrm{O}_{3} / \mathrm{HfO}_{2}$, (c,f) bilayer IGZO TFTs with (c) $\mathrm{HfO}_{2}$ and (f) $\mathrm{Al}_{2} \mathrm{O}_{3} / \mathrm{HfO}_{2}$. The stress conditions are $V_{G S}=V_{T H}+10 \mathrm{~V}$ at $60^{\circ} \mathrm{C}$. 
(a)

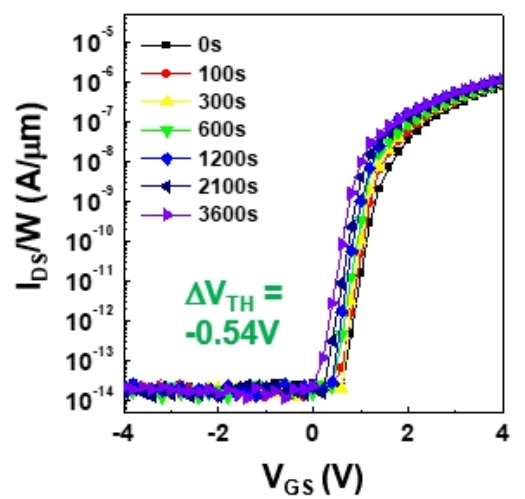

(d)

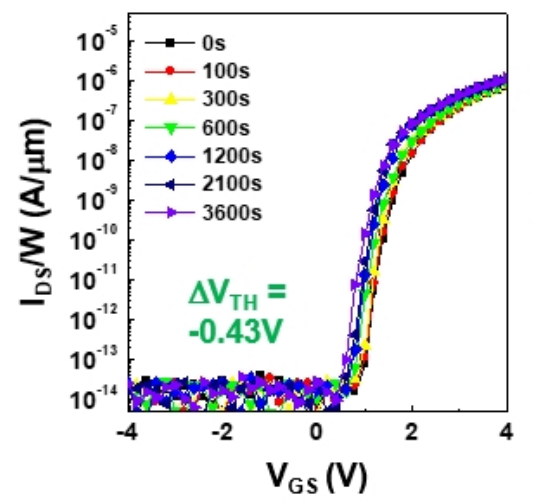

(b)

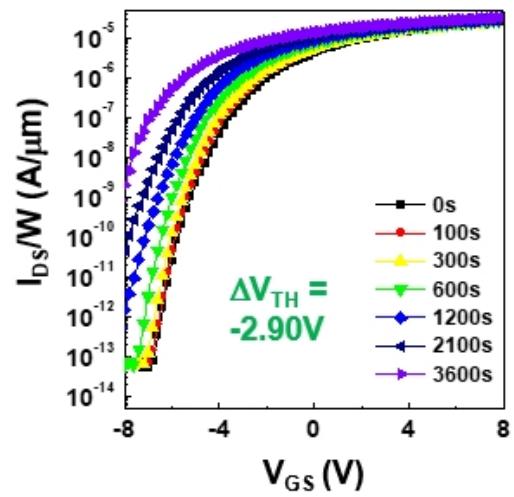

(e)

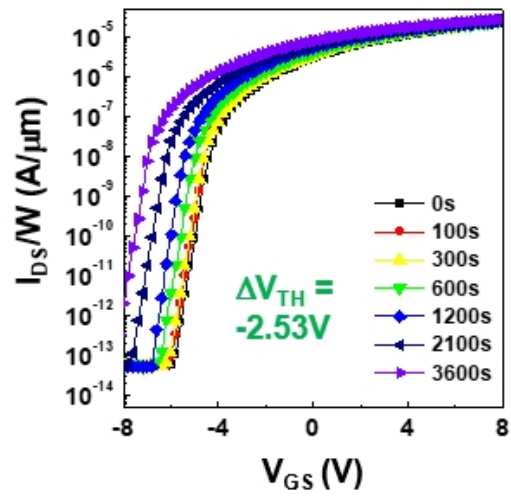

(c)

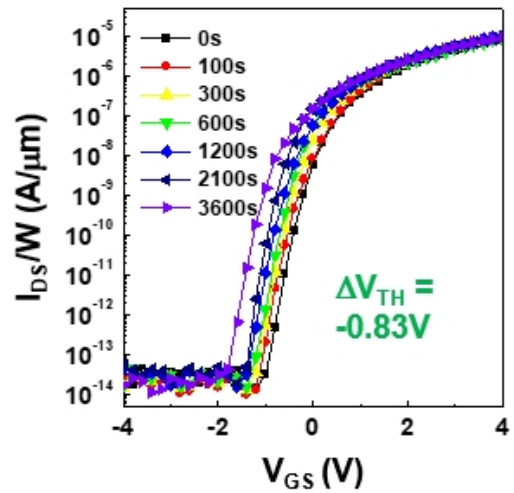

(f)

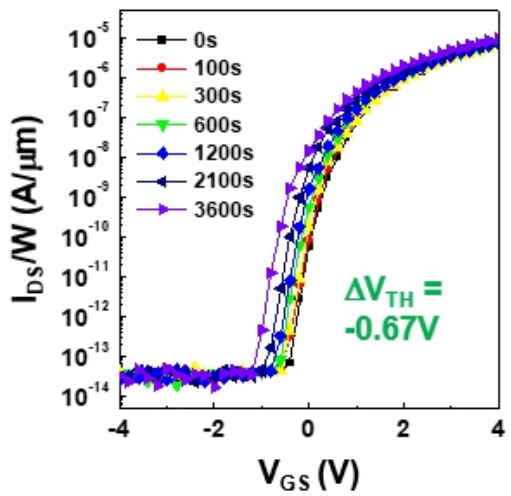

Figure S17. Evolution of time-dependent transfer characteristics of ALD-derived IGZO TFTs with various gate insulator; (a,d) base layer IGZO TFTs with (a) $\mathrm{HfO}_{2}$ and (d) $\mathrm{Al}_{2} \mathrm{O}_{3} / \mathrm{HfO}_{2}$, (b,e) boost layer IGZO TFTs with (b) $\mathrm{HfO}_{2}$ and (e) $\mathrm{Al}_{2} \mathrm{O}_{3} / \mathrm{HfO}_{2}$, (c,f) bilayer IGZO TFTs with (c) $\mathrm{HfO}_{2}$ and (f) $\mathrm{Al}_{2} \mathrm{O}_{3} / \mathrm{HfO}_{2}$. The stress conditions are $V_{G S}=V_{T H}-10 \mathrm{~V}$ and a light intensity of $0.066 \mathrm{~mW} / \mathrm{cm}^{2}$ (light source with a wavelength of $\sim 533 \mathrm{~nm}$ with full-width at half maximum of approximately $\pm 10 \mathrm{~nm}$ ). 
(a)

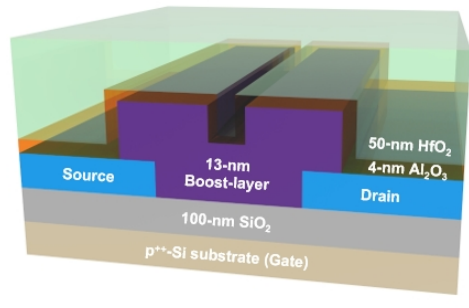

(b)

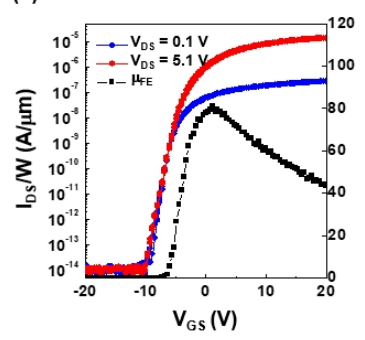

(c)

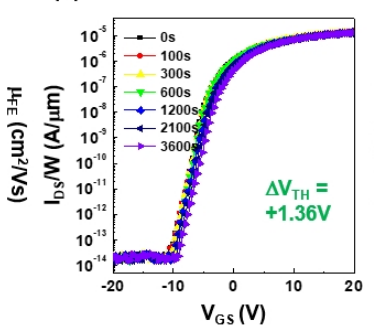

(d)

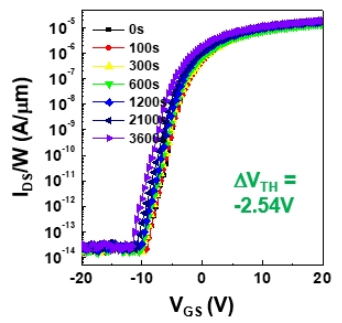

Figure S18. (a) Schematic diagram of the bottom gate structure boost layer IGZO TFT with $\mathrm{SiO}_{2}(100$ $\mathrm{nm})$ gate insulator and (b) corresponding transfer characteristics. (c,d) Evolution of time-dependent transfer characteristics of bottom gate structure boost layer IGZO TFT with $\mathrm{SiO}_{2}(100 \mathrm{~nm})$ gate insulator under (c) PBTS and (b) NBIS conditions for 3,600 sec.

Table S9. Summary of electrical parameters: $\mu_{F E}, S S$, and $V_{T H}$, and $I_{O N / O F F}$ of the boost layer IGZO TFT with $\mathrm{SiO}_{2}(100 \mathrm{~nm})$ gate insulator through PDA at $500^{\circ} \mathrm{C}$ for $1 \mathrm{~h}$ in air ambient.

\begin{tabular}{cccccccc}
\hline Channel & $\begin{array}{c}\text { Gate } \\
\text { Insulator }\end{array}$ & $\begin{array}{c}C_{O X} \\
{\left[\mathrm{nF} / \mathrm{cm}^{2}\right]}\end{array}$ & $\begin{array}{c}\mu_{F E} \\
{\left[\mathrm{~cm}^{2} /(\mathrm{V} \mathrm{s})\right]}\end{array}$ & $\begin{array}{c}S S \\
{[\mathrm{~V} / \mathrm{dec}]}\end{array}$ & $\begin{array}{c}V_{T H} \\
{[\mathrm{~V}]}\end{array}$ & $\begin{array}{c}I_{O N / O F F} \\
{\left[\times 10^{7}\right]}\end{array}$ & $\begin{array}{c}N_{T, m a x} \\
{\left[\mathrm{~cm}^{-3} \mathrm{ev}^{-1}\right]}\end{array}$ \\
\hline $\begin{array}{c}\mathrm{In}_{0.82} \mathrm{Ga}_{0.08} \mathrm{Zn}_{0.10} \mathrm{O} \\
\text { (Boost layer) }\end{array}$ & $\begin{array}{c}100 \mathrm{~nm} \\
\mathrm{SiO}_{2}\end{array}$ & 34.5 & $81.3 \pm 4.04$ & $0.97 \pm 0.02$ & $-6.08 \pm 2.16$ & $\sim 29.4$ & $2.70 \times 10^{18}$ \\
\hline
\end{tabular}



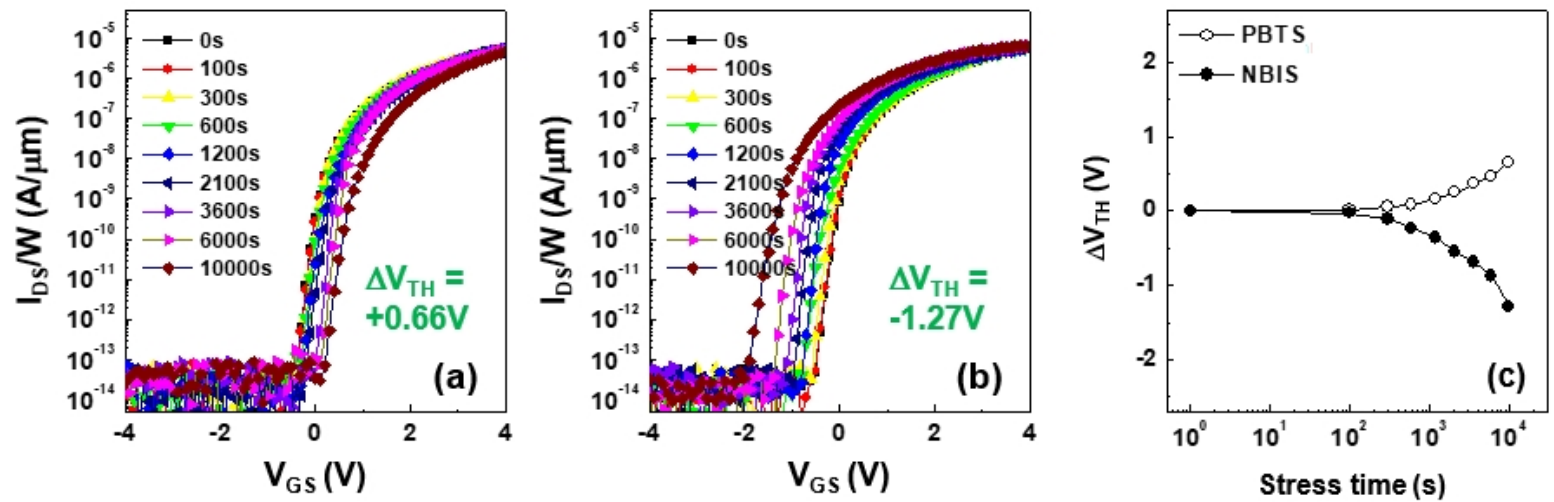

Figure S19. Variations in the transfer characteristics for the bilayer IGZO TFT with gate insulator of $\mathrm{Al}_{2} \mathrm{O}_{3}(4 \mathrm{~nm}) / \mathrm{HfO}_{2}(50 \mathrm{~nm})$ stack under (a) PBTS and (b) NBIS conditions for $10,000 \mathrm{sec}$. (c) Corresponding $V_{T H}$ shift as a function of the stress time. 

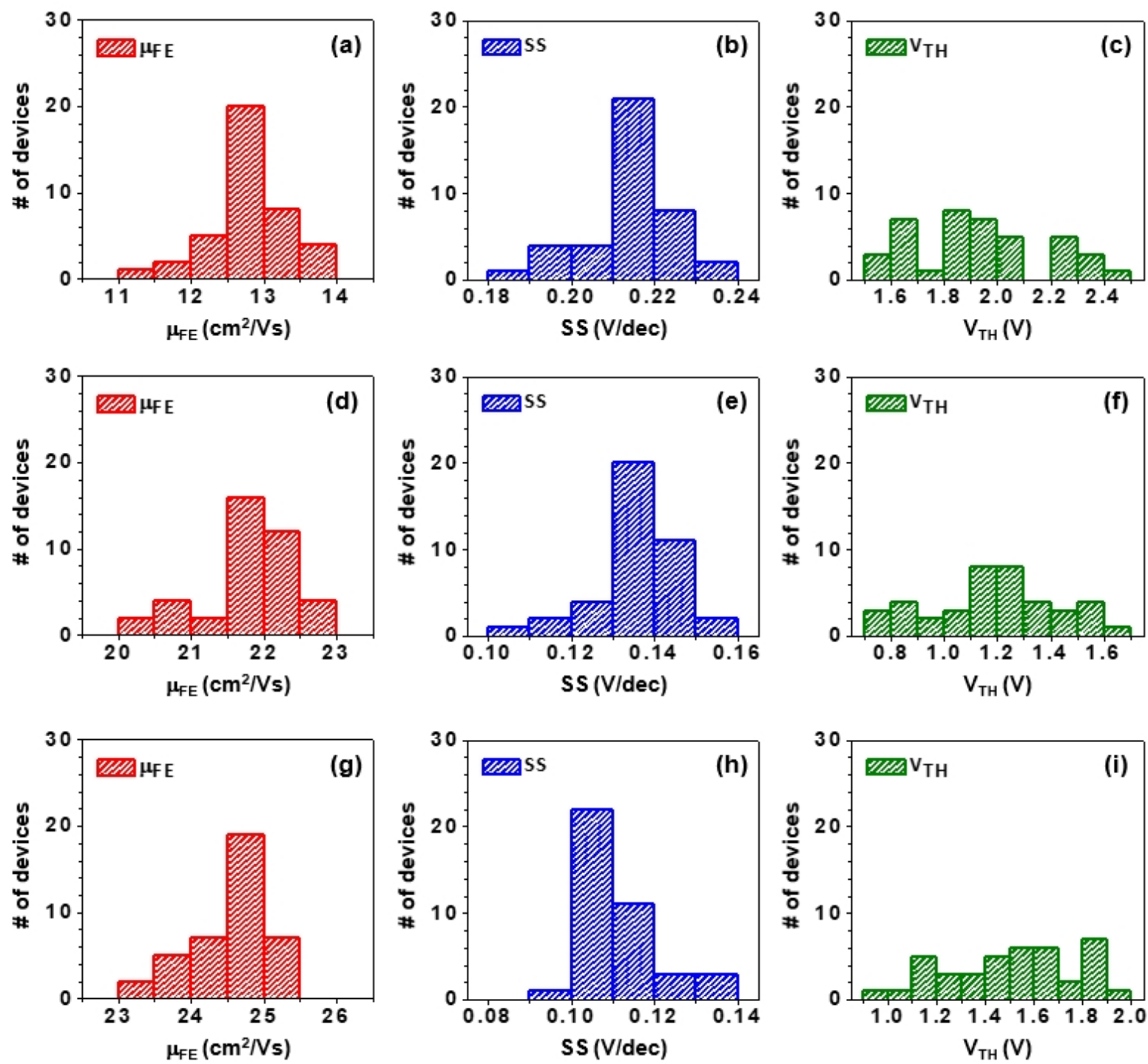

Figure S20. Distribution of (a, d, g) $\mu_{F E}$, (b, e, h) $S S$, and (c, f, i) $V_{T H}$ for the base layer IGZO TFTs with (a-c) $\mathrm{Al}_{2} \mathrm{O}_{3}$, (e-f) $\mathrm{HfO}_{2}$, and (g-i) $\mathrm{Al}_{2} \mathrm{O}_{3} / \mathrm{HfO}_{2}$ gate insulator. These data were for 40 different transistors. 

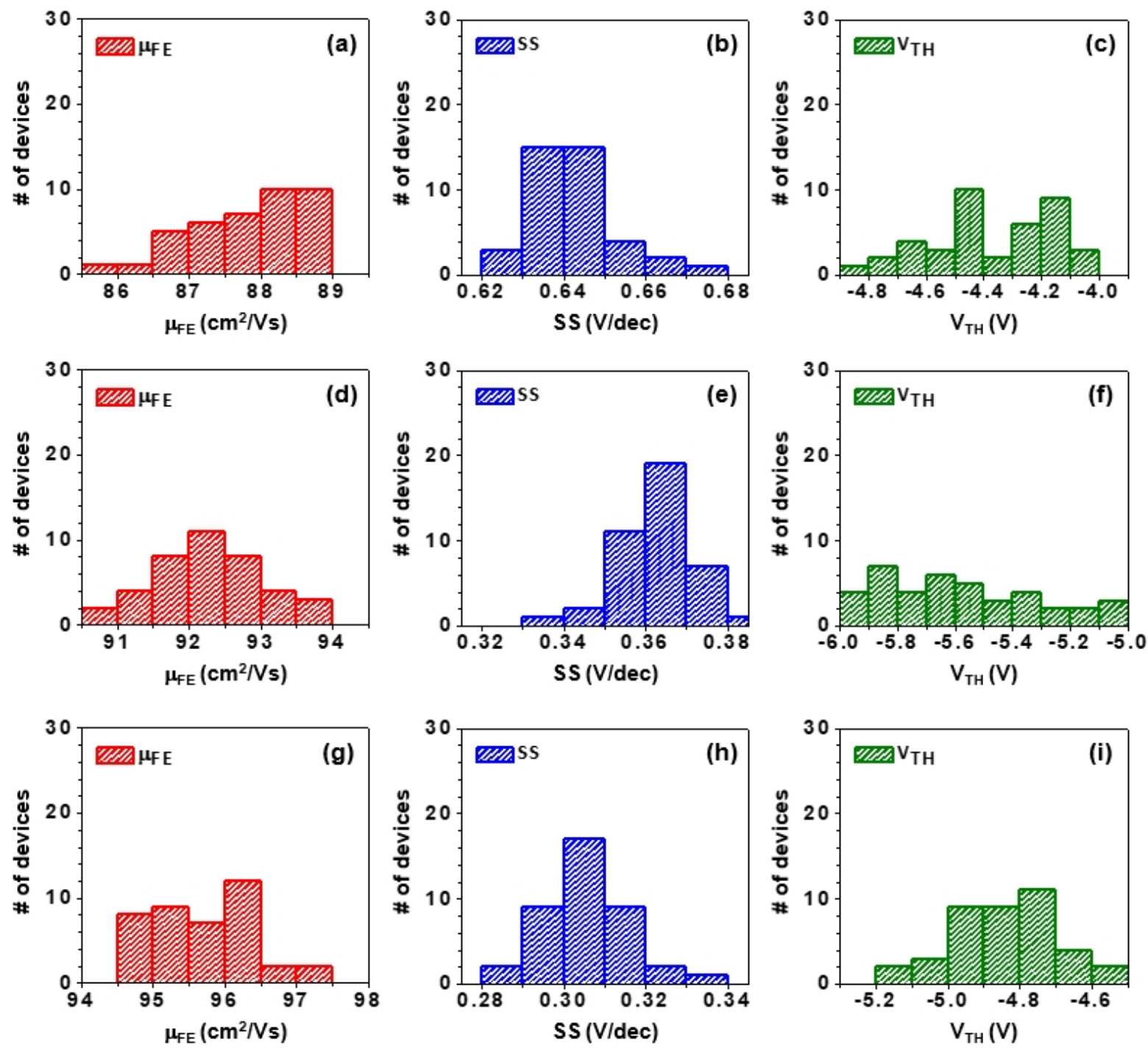

Figure S21. Distribution of (a, d, g) $\mu_{F E}$, (b, e, h) $S S$, and (c, f, i) $V_{T H}$ for the boost layer IGZO TFTs with (a-c) $\mathrm{Al}_{2} \mathrm{O}_{3}$, (e-f) $\mathrm{HfO}_{2}$, and (g-i) $\mathrm{Al}_{2} \mathrm{O}_{3} / \mathrm{HfO}_{2}$ gate insulator. These data were for 40 different transistors. 

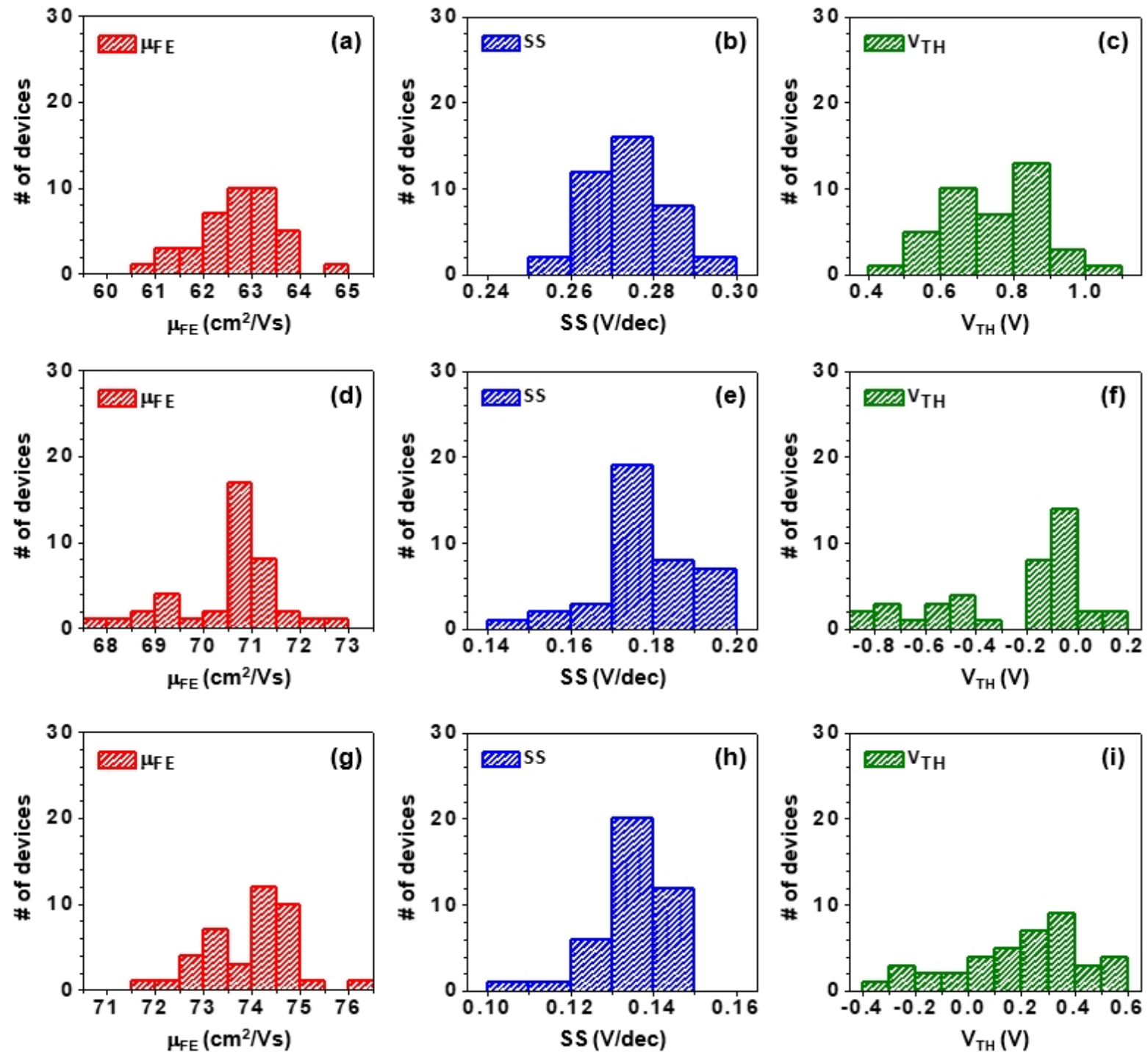

Figure S22. Distribution of (a, d, g) $\mu_{F E}$, (b, e, h) $S S$, and (c, f, i) $V_{T H}$ for the bilayer IGZO TFTs with (a-c) $\mathrm{Al}_{2} \mathrm{O}_{3}$, (e-f) $\mathrm{HfO}_{2}$, and (g-i) $\mathrm{Al}_{2} \mathrm{O}_{3} / \mathrm{HfO}_{2}$ gate insulator. These data were for 40 different transistors. 